Efektivitas Instagram dalam Meningkatkan Minat Kunjungan Wisatawan di Daerah Istimewa Yogyakarta

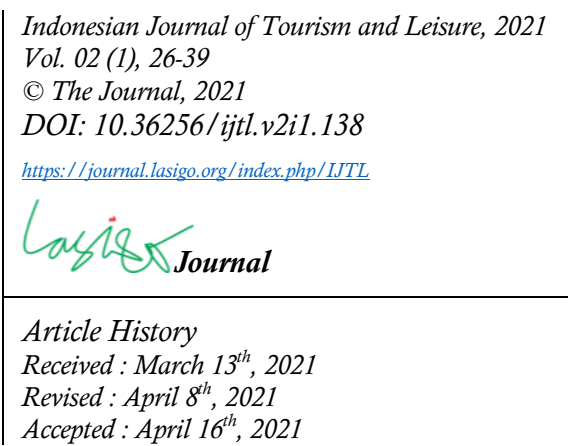

\title{
Ani Wijayanti
}

Universitas Bina Sarana Informatika, Yogyakarta, Indonesia Email: ani.awi@bsi.ac.id

\begin{abstract}
Promotion and marketing through social media becomes a strategic issue during a pandemic, due to there are various restrictions on activities. One of the popular social media is Instagram. Instagram provides features for editing photos, editing videos, messaging, sharing photos and videos, and sharing reviews or reviews. The Yogyakarta Special Region tourism office (D.I.Y) uses Instagram as the main social media in the promotion and marketing of tourist destinations in D.I.Y. This study aims to review the effectiveness of the use of Instagram by measuring the extent to which the influence of the ability of tourists to access Instagram and the quality of Instagram on the interest in tourist visits in the Special Region of Yogyakarta. The study used a quantitative descriptive approach by conducting a survey of 200 respondents. Data measurement used a 5point Likert scale and analyzed using linear regression techniques. The results showed that there was a significant positive influence between the ability of tourists to access Instagram and the quality of Instagram on the visiting interest, both partially and simultaneously. The quality of Instagram has a dominant influence of 40\%, compared to the ability of tourists to access Instagram, which is $19.9 \%$. The variable access ability and quality of Instagram contributed $53.2 \%$ to the visiting interest, while the remaining $46.8 \%$ was explained by other variables not involved in this study.
\end{abstract}

Keywords: Instagram; Visiting Interest; Promotion; Social Media

\begin{abstract}
ABSTRAK
Promosi dan pemasaran melalui media sosial menjadi isu strategis pada masa pandemi, dimana terjadi berbagai pembatasan aktivitas. Salah satu media sosial yang popular yakni Instagram. Instagram menyediakan fitur edit foto, edit video, olah pesan, berbagi foto dan video, serta berbagi review atau ulasan. Dinas pariwisata Daerah Istimewa Yogyakarta (D.I.Y) menggunakan Instagram sebagai media sosial utama dalam promosi dan pemasaran destinasi wisata di D.I.Y. Penelitian ini bertujuan mengulas efektifitas pemanfaatan Instagram dengan mengukur sejauhmana pengaruh kemampuan wisatawan mengakses Instagram dan kualitas Instagram terhadap minat kunjungan wisatawan di Daerah Istimewa Yogyakarta. Penelitian menggunakan pendekatan deskriptif kuantitatif dengan melakukan survei pada 200 responden. Pengukuran data menggunakan skala likert 5 poin dan dianalisa menggunakan teknik regresi linear. Hasil penelitian menunjukkan terdapat pengaruh positif siginifikan antara kemampuan wisatawan mengakses Instagram dan kualitas Instagram terhadap minat kunjungan wisatawan, baik secara parsial maupun simultan. Kualitas Instagram mempunyai pengaruh dominan sebesar $40 \%$, dibandingkan kemampuan wisatawan mengakses Intagram yakni 19,9\%. Variabel
\end{abstract}


kemampuan mengakses dan kualitas Instagram bekontribusi sebesar 53,2\% terhadap minat kunjungan wisatawan, sedangkan sisanya sebesar 46,8\% dijelaskan oleh variabel lain yang tidak dilibatkan dalam penelitian ini.

Kata Kunci: Instagram; Minat Kunjungan; Promosi; Media Sosial.

\section{Pendahuluan}

Media sosial merupakan platform yang menyediakan fasilitas kolaborasi yang mampu menguatkan relasi dan menciptakan jalinan sosial diantara pengguna tanpa terbatas jarak, ruang, dan waktu (Nasrullah, 2015). Media sosial mengubah cara perusahaan dalam mengkomunikasikan produknya kepada pelanggan secara mendasar. Perusahaan tidak hanya menggunakan media sosial sebagai media promosi, tetapi lebih jauh lagi sebagai media menjalin dan memelihara persahabatan dengan pelanggan (Saravanakumar, M; Lakshmi, 2012).

Pemanfaatan media sosial sebagai media promosi di masa pandemi menjadi solusi yang sangat strategis. Pada masa pandemi terjadi penurunan daya beli masyarakat serta krisis kepercayaan sehingga minat kunjungan wisatawan menurun secara drastis. Penurunan daya beli masyarakat sendiri sangat dipengaruhi oleh terpuruknya kondisi perekonomian selama pandemi, sedangkan krisis kepercayaan terhadap pengelolaan destinasi wisata yang mematuhi protokol kesehatan masih sangat tinggi. Pemanfaatan Instagram untuk mengembalikan kepercayaan wisatawan dan menumbuhkan minat kunjungan sangat diperlukan dimasa pandemi, dimana terjadi pembatasan mobilitas dalam skala besar. Media sosial memungkinkan aktivitas promosi dan pemasaran tanpa harus melakukan perjalanan dan bertatap muka dengan pelanggan. Pemasaran menggunakan media sosial mampu menjangkau pelanggan dalam jumlah besar dan skala luas.

Media online menjadi wadah bagi para pengguna yang memiliki minat sama untuk berbagi ide, pemikiran, pendapatan, dan gagasan dalam lingkungan online (Weber, 2007). Media sosial mampu mewujudkan penyampaian informasi bisnis dan komersial yang dikemas dalam konteks hiburan, sehingga muatannya terasa ringan dan mudah diterima oleh masyarakat luas. Konsep hiburan dalam mengemas konten pemasaran mampu mewujudkan hubungan emosional positif antara konsumen dan merek (Hudson \& Hudson, 2006) yang akan dibagikan pada berbagai pihak dan mempengaruhi minat pembelian (Dobele, Lindgreen, Beverland, Vanhamme, \& van Wijk, 2007). Media sosial memungkinkan proses pertukaran, kolaborasi, partisipasi, dan kontribusi dalam komunitas secara online, diantaranya Blog, Wiki, Facebook, Linked, Twitter, YouTube, dan Instagram (Dewing, 2017).

Instagram merupakan salah satu media yang banyak diminati oleh pelanggan karena fiturnya yang sangat inovatif dan kreatif, sehingga banyak pengusaha yang mengalokasikan investasi pada media sosial Instagram pada tahun 2021. Dalam Social Trend Report 2021 tercatat investasi pada Instagram menduduki peringkat pertama, yakni 61\%, sementara media sosial Facebook, YouTube, dan Linked tercatat pada kisaran $40 \%$. Twitter dan Whatsapp juga relatif kecil, yakni pada angka $26 \%$ dan $17 \%$, seperti disajikan pada Gambar 1 .

Berdasarkan data Hootsuite atau We are Sosial tahun 2020 total populasi penduduk Indonesia sebesar 272,1 juta, dengan pengguna internet sebanyak 175,4 juta, sedangkan pengguna media sosial aktif sebanyak 160 juta. Adapun jumlah pengguna Instagram di Indonesia sebanyak 79\% dari jumlah populasi, yakni 63 juta jiwa, dengan jumlah pengguna perempuan sebanyak 50,8\% dan Laki-laki 49,2\%. Berdasarkan laporan digital 2020-2021 pada triwulan III 2020 Instagram naik ke peringkat ketiga melampaui Facebook, hal ini menunjukkan Instagram merupakan salah satu media sosial yang banyak diminati. Oleh karena itu, Kementerian Pariwisata RI sendiri menggunakan media Instagram sebagai media promosi yang dianggap cukup efektif. Kemenpar RI memaksimalkan promosi melalui Instagram untuk meningkatkan 
jumlah wisatawan baik dalam skala nasional maupun internasional, melalui beberapa tahapan, yakni; penciptaan konten, penentuan platform, perencanaan program, implementasi program, monitoring, dan evaluasi.

Gambar 1. Grafik Investasi Media Sosial pada Tahun 2021

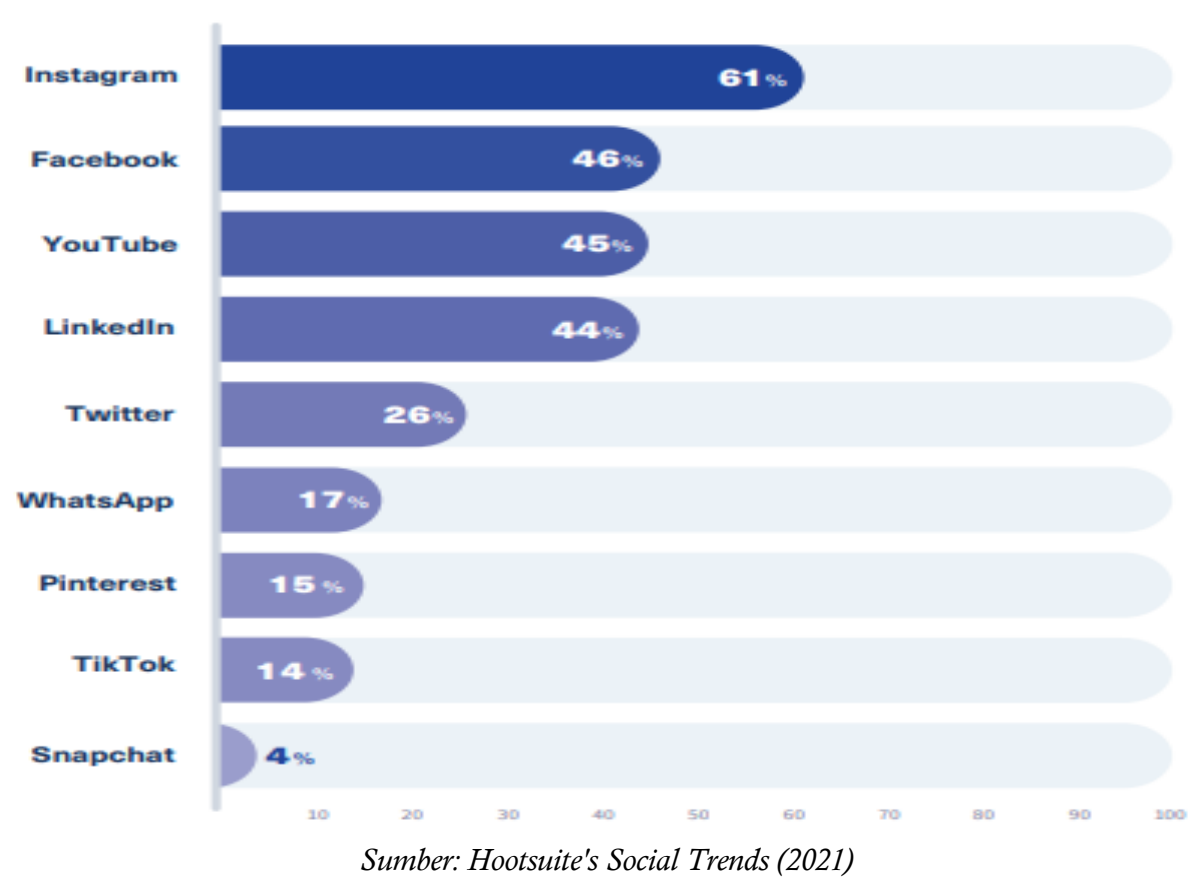

Pemanfaatan Instagram mampu mewujudkan kesadaran wisatawan sebagai target market akan keragaman budaya dan keindahan alam (Atiko, Hasanah Sudrajat, \& Nasionalita, 2016). Instagram menjadi salah satu media yang digunakan wisatawan dalam menentukan destinasi wisata yang akan dikunjungi melalui ulasan atau review dari wisatawan yang sudah berkunjung terlebih dahulu (Jalilvand \& Samiei, 2012). Berbagai informasi dan review dari wisatawan menjadi referensi dalam menentukan destinasi wisata yang akan dikunjungi. Review dalam Instagram menjadi sebuah komunikasi word of mouth online atau disebut electronic word of mouth (e-WoM) yang memiliki empat dimensi, yaitu 1). Intensitas yakni jumlah opini yang ditulis wisatawan, 2). Komentar atau opini positif, 3). Komentar atau opini negatif, dan 4). Konten (Goyette, Ricard, \& Bergeron, 2010). Instagram menjadi sarana komunikasi timbal balik antara pengelola dengan wisatawan untuk menyampaikan kelebihan dan kekurangan produk sekaligus loyalitas wisatawan (Martin \& Todorov, 2010). Komentar negatif muncul sebagai akibat dari ketidakpuasan konsumen terhadap produk maupun jasa layanan. Komentar positif di media sosial mampu meningkatkan minat pembelian atau kunjungan pada sebuah destinasi, sebaliknya komentar negatif berdampak pada berkurang sampai hilangnya minat kunjungan wisatawan (Baker \& Donthu, 2015; Doh \& Hwang, 2009). Minat wisata merupakan perilaku yang memotivasi seseorang melakukan kunjungan pada sebuah destinasi (Rezvani et al., 2012). Sedangkan, minat pembelian merupakan kombinasi antara minat konsumen dan keinginan membeli suatu produk (Kim \& Ko, 2012).

Instagram sebagai media sosial strategis untuk promosi dan pemasaran wisata mempunyai kelebihan dan kekurangan. Kelebihan Instagram yakni aksesibilitas, efektifitas, efisiensi, dan jangkauan yang sangat luas tanpa terbatas ruang dan waktu. Pemasaran menggunakan Instagram mampu mewujudkan popularitas merek, meningkatkan volume penjualan, dan eksposur bisnis dalam skala besar dengan biaya sangat minim atau hampir tanpa biaya (Neti, 2011). Sedangkan kelemahan Instagram yakni dampak dari review negatif wisatawan yang secara cepat membentuk opini buruk bagi masyarakat luas. Situs jejaring Instagram memungkinkan 
pelanggan memberi ulasan baik maupun buruknya sebuah produk yang mempunyai pengaruh besar dan mampu meyakinkan pelanggan (Jadhav, et al., n.d.). Kelemahan lainnya, yakni tidak semua wisatawan familiar dengan teknologi, sehingga terdapat potensi kehilangan pasar sebagai dampak perkembangan ilmu dan teknologi.

Perubahan perilaku wisatawan dimasa pandemi berdampak pada perubahan strategi pemasaran semua bisnis, tidak terkecuali pemasaran destinasi wisata di Daerah Istimewa Yogyakarta (D.I.Y). Pola konsumsi wisatawan yang sebelumnya dilakukan secara offline mengalami perubahan menjadi online. Pemanfaatan media sosial yang belum optimal menjadi dominan untuk menjangkau target pasar pada masa pandemi. Hal tersebut juga dilakukan Dinas Pariwisata D.I.Y yang menjadikan media sosial sebagai pilihan utama media promosi dan pemasaran, diantaranya, Facebook, YouTube, Instagram, Website, dan Twitter. Penelitian ini mengupas salah satu media sosial yang paling banyak diminati, dilihat dari jumlah pengikut yang terbanyak, yakni Instagram. Tujuan penelitian adalah mengetahui sejauhmana efektifitas pemanfaatan Instagram dengan mengukur sejauhmana pengaruh kemampuan wisatawan dalam mengakses Instagram dan Kualitas Instagram yang berdampak pada minat wisatawan dalan mengunjungi sebuah destinasi wisata. Hipotesis penelitian yakni terdapat pengaruh positif signifikan antara kemudahan mengakses dan kualitas Instagram dengan minat kunjungan wisata baik secara parsial maupun simultan.

\section{Tinjauan Pustaka}

\subsection{Media Sosial alat Pemasaran Strategis}

Strategi pemasaran yang tepat sangat menentukan keberlanjutan sebuah bisnis. Analisis atau riset pasar sangat perlu dilakukan untuk menentukan media pemasaran yang tepat, baik secara online maupun offline. Riset pasar diperlukan untuk memprediksi dampak pengambilan keputusan pada kinerja pemasaran yang diterapkan (Rochman \& Iskandar, 2015). Pada masa pandemi situs jejaring sosial menjadi isu hangat bagi pemasar (Zarrella, 2009) dan diakui sebagai platform pemasaran yang potensial (Neti, 2011). Jejaring sosial memberikan ruang interaksi antara perusahaan dengan pelanggan dan antara pelanggan kapan saja dan dimana saja (Cowden, 2014). Teknik pemasaran sendiri dapat dilakukan dalam tiga cara, yakni pemasaran tanpa menentukan target pasar, pemasaran yang menargetkan pada pasar yang spesifik, dan pemasaran gabungan dari keduanya. Pada teknik pemasaran yang tidak menentukan target pasar terlebih dahulu mempunyai keuntungan berupa pasar yang lebih luas, namun segmentasi pasar kurang jelas, sehingga pengembalian investasi juga kurang bisa diprediksi. Media yang digunakan pada teknik pemasaran ini, diantaranya; media elektronik, seperti televisi, radio, media sosial, dan baliho. Berbeda dengan teknik pemasaran yang kedua, pasar lebih tersegmentasi. Meskipun tidak mempunyai pasar yang luas namun lebih bisa diprediksi sejauhmana ketercapaian kinerja pemasarannya. Media yang digunakan, diantaranya email dan sponsorship. Sedangkan, teknik pemasaran ketiga, yakni menggabungkan kedua pemasaran dengan tujuan mengoptimalkan proses promosi dan pemasaran untuk menjangkau pasar yang luas dan besar.

Salah satu pilihan media yang strategis untuk pemasaran, yakni Instagram. Instagram mendesain platformnya sangat strategis, yakni mampu mengkoneksikan gambar yang lebih menarik untuk promosi dibandingkan dengan YouTube, Twitter, Facebook, dan media sosial lainnya. Gambar dan video yang diposting di Instagram mampu menjadi umpan balik yang positif bagi perusahaan dan pelanggan (Knibbs, 2013), sehingga Instagram ditetapkan sebagai penguasa tertinggi jagat media sosial (Uzunian, 2013). Bagi kaum milenial Instagram merupakan salah satu media sosial yang sangat diminati, karena mempunyai karakteristik sesuai dengan kaum milenial, yakni memiliki fitur yang aplikatif, kreatif, dan inovatif. Penggunaan Instagram memungkinkan mereka untuk berbagi video dan gambar secara realtime dengan cara yang relatif mudah. 
Instagram berasal dari kata Instan dan Telegram, yang muncul dari aplikasi bernama Burbn. Aplikasi Burn diciptakan oleh Kevin Systrom dan Mike Krieger dengan fasilitas check in lokasi dan posting foto, namun pada akhirnya lebih memfokuskan pada fungsi aplikasi foto sehingga nama Burn diganti menjadi Telegram (Maravic, 2013) yang berdiri pada tahun 2010 (Bergström \& Bäckman, 2013). Pada awalnya Instagram hanya memiliki fitur edit dan berbagi foto, selanjutnya berkembang dengan fitur lainnya yakni berbagi video dan pesan foto secara langsung kepada pengguna lainnya (Dennis, 2014).

Instagram merupakan aplikasi seluler yang memudahkan wisatawan mengambil foto dan video dimana saja dan kapan saja, kemudian membagikannya secara langsung baik secara nasional maupun internasional kepada pengguna lainnya (Dennis, 2014). Pengguna Instagram dapat mengambil video dalam durasi waktu tertentu dan mengedit atau mengkreasi menggunakan filter artistik yang tersedia (Bevins, 2014). Instagram mempunyai keunggulan dibandingkan media sosial lain, yakni memfokuskan pada fitur foto (Linaschke, 2011) dan berbasis visual (Hird, 2013). Pemasaran produk menggunakan Instagram yang berbasis foto sangat efektif dan efisien, karena gambar mampu berbicara seribu kata (Silva, Melo, Almeida, Salles, \& Loureiro, 2013) dan instagram menyediakan fitur filter dan edit gambar secara langsung (Herman, 2014). Instagram memiliki fitur hashtag (\#) untuk memudahkan dalam penunjukkan foto dan video yang relevan dengan produk (Dennis, 2014), serta memiliki fitur perpesanan langsung yang memungkinkan pengguna berinteraksi dengan pengelola secara privat (Herman, 2014). Promosi menggunakan Instagram dapat dilakukan dengan empat tahapan, yakni kehadiran komunikator, olah pesan, media, dan komunikan (Kurniawati, 2017).

\subsection{Instagram Menumbuhkan Minat Kunjung Wisatawan}

Penggunaan Instagram sebagai media interaksi sosial secara online telah berkembang sebagai media promosi dan pemasaran produk industri pariwisata. Pemanfaatan media sosial berdampak pada pencitraan sebuah destinasi wisata (Ellya, 2015) dan meningkatkan minat beli wisatawan yakni mengunjungi destinasi wisata (Deru \& Cindy, 2017). Minat beli muncul sebagai dampak kebutuhan dan proses evaluasi kelayakan produk, salah satunya melalui review atau ulasan pada media sosial Instagram (Madahi \& Sukati, 2012). Minat beli merupakan perilaku kognitif konsumen (Kwek, Tan, \& Lau, 2010), yakni penilaian terhadap sebuah produk (Setiawan, 2017) dan niat untuk membeli produk itu sendiri (Teng, Laroche, \& Zhu, 2007). Minat beli merupakan sebuah proses pengambilan keputusan dalam proses evaluasi, pembelian, dan pemanfaatan produk (Schiffman \& Kanuk, 2007). Minat beli berlanjut menjadi tindakan pembelian nyata apabila pelanggan mempunyai komitmen positif akan sebuah merek (Schiffman \& Kanuk, 2007), serta dorongan kuat dari eksternal melalui e-WoM tentang produk dan harga (Lin, Lu, \& Wu, 2012). Minat beli dapat diukur melalui tiga indikator yakni rekomendasi, pertimbangan, dan kesediaan membeli (Shih, 2010).

Instagram mampu menumbuhkan minat beli wisatawan dari pengalaman berupa foto maupun video yang dibagikan sebagai bentuk interaksi antara pengguna dan sumber referensi destinasi wisata (Trihayuningtyas et al., 2019). Terdapat dua cara efektif dalam pemanfaatan Instagram sebagai media komunikasi pemasaran digital, yakni social media maintenance dan social media endorsement. Social media maintenance dilakukan melalui pemanfaatan fitur caption, location, hashtag, tagging, Instagram ads, video, foto, dan comment untuk berinteraksi dengan pengguna, sedangkan social media endorsement melalui proses endorsement menggunakan public figure untuk meningkatkan jumlah follower (Kusuma \& Sugandi, 2019). Penggunaan public figure sebagai influencer menjadi salah satu cara strategis meningkatkan minat beli, karena pengguna cenderung mengikuti gaya hidup mereka (Djafarova \& Rushworth, 2017), serta menjadi modalitas visual yang berpengaruh dalam e-WoM (Lin et al., 2012). Instagram juga menjadi alat pemasaran utama bagi perusahaan yang mempunyai target pasar milenial (Rizky \& Setiawati, 2020), karena mereka relatif aktif terlibat dalam platform ini (Carah \& Shaul, 2016). 


\section{Metode}

Penelitian ini menggunakan pendekatan deskriptif kuantitatif dengan mengambil lokasi destinasi wisata Daerah Istimewa Yogyakarta (D.I.Y). Data penelitian diambil menggunakan kuesioner online yang dibagikan kepada 200 wisatawan di D.I.Y, sekaligus pengguna Instagram. Pemilihan jumlah responden berdasarkan teori dari (Sugiyono, 2011), yakni ukuran sampel dalam penelitian sebesar 30 sampai dengan 500. Adapun teknik pengumpulan data dilakukan dengan cara purposive random sampling, yakni sampel dipilih dengan memenuhi persyaratan diantaranya pengguna Instagram dan pernah mengunjungi destinasi Wisata di Daerah Istimewa Yogyakarta. Proses pengumpulan data dilakukan selama satu bulan, yakni bulan Februari 2021. Data dianalisa dengan teknik regresi linear menggunakan alat analisa SPSS. Adapun pengukuran menggunakan skala Likert 1 s.d 5, yakni Sangat Tidak Setuju (STS), Tidak Setuju (TS), Raguragu (RG), Setuju (S), dan Setuju Sekali (SS). Instrumen penelitian menggunakan kuesioner yang telah diuji validitas dan reliabilitasnya, seperti disajikan pada Tabel 1.

Tabel 1. Uji Instrumen

\begin{tabular}{llllll}
\hline Var & r.hit & Sig & Var & r.hit & Sig \\
\hline $\mathrm{X} 1.1$ & 0,836 & 0,000 & $\mathrm{X} 2.1$ & 0,897 & 0,000 \\
$\mathrm{X} 1.2$ & 0,786 & 0,000 & $\mathrm{X} 2.2$ & 0,921 & 0,000 \\
$\mathrm{X} 1.3$ & 0,806 & 0,000 & $\mathrm{X} 2.3$ & 0,910 & 0,000 \\
$\mathrm{X} 1.4$ & 0,811 & 0,000 & $\mathrm{X} 2.4$ & 0,887 & 0,000 \\
$\mathrm{X} 1.5$ & 0,831 & 0,000 & $\mathrm{X} 2.5$ & 0,869 & 0,000 \\
$\mathrm{X} 1.6$ & 0,696 & 0,000 & $\mathrm{Y} 1.1$ & 0,922 & 0,000 \\
$\mathrm{X} 1.7$ & 0,645 & 0,000 & $\mathrm{Y} 1.2$ & 0,927 & 0,000 \\
$\mathrm{X} 1.8$ & 0,605 & 0,000 & $\mathrm{Y} 1.3$ & 0,920 & 0,000 \\
& & & $\mathrm{Y} 1.4$ & 0,827 & 0,000 \\
\hline
\end{tabular}

Sumber: DataPeneliti (2021)

Pada Tabel 1 tercatat bahwa nilai $\mathrm{r}$ hitung dan nilai signifikansi dari setiap indikator penelitian. Penentuan nilai reliabilitas dilakukan dengan membandingkan nilai $\mathrm{r}$ hitung dengan nilai $\mathrm{r}$ tabel, apabila nilai $\mathrm{r}$ hitung lebih besar dari nilai $\mathrm{r}$ tabel, maka indikator dinyatakan reliabel. Nilai $\mathrm{r}$ tabel pada responden berjumlah 200 dengan signifikansi $5 \%$, yakni 0,138 . Nilai $\mathrm{r}$ hitung pada semua indikator berada dalam kisaran 0,604 s.d 0,927 >0,138, maka dapat disimpulkan bahwa semua indikator reliabel. Nilai validitas dilihat dengan cara membandingkan nilai signifikansi hitung dengan nilai signifikansi 0,05 , apabila nilai signifikansi hitung lebih kecil dari 0,05, maka indikator dinyatakan valid. Pada Tabel 1 tercatat nilai signifikansi hitung semua indikator adalah $0,000<0,05$, maka semua indikator dalam penelitian ini valid.

Penelitian menggunakan tiga variabel penelitian yang terdiri dari dua variabel bebas atau dan satu variabel terikat. Variabel bebas meliputi kemampuan wisatawan mengakses instagram dan persepsi responden terhadap kualitas Instagram, sedangkan variabel terikat, yakni minat kunjungan wisatawan. Adapun definisi operasional variabel penelitian disajikan pada Tabel 2.

Tabel 2. Definisi Operasional Variabel Penelitian

\begin{tabular}{lll}
\hline Variabel & Indikator & $\begin{array}{l}\text { Skala } \\
\text { Pengukuran }\end{array}$ \\
\hline Kemampuan wisatawan mengakses & Ketersediaan perangkat (X1.1) & Skala Likert \\
instagram (X1) & Kemampuan mengoperasikan media sosial (X1.2) & Skert \\
Jejaring sosial memberikan ruang & Ketersediaan kuota (X1.3) & Skala Likert \\
interaksi antara perusahaan dengan & Kemampuan mengakses dimana saja (X1.4) & Skala Likert \\
pelanggan dan antara pelanggan & Kemampuan mengakses kapan saja (X1.5) & Skala Likert \\
kapan saja dan dimana saja & Ketersediaan waktu cukup (X1.6), & Skala Likert \\
(Cowden, 2014) & Mengakses media sosial untuk mendapatkan informasi (X1.7) & Skala Likert \\
& Mengakses media sosial untuk komunikasi (X1.8) & Skala Likert \\
Kualitas Instagram (X2). & Tampilan yang menarik (X2.1) & Skala Likert \\
instagram memiliki berbagai fitur & Informasi yang up to date (X2.2) & Skala Likert
\end{tabular}


yaitu edit dan berbagi foto dan video secara langsung kepada pengguna lainnya (Dennis, 2014)

Minat kunjungan wisatawan (Y)

Proses pengambilan keputusan dalam proses evaluasi, pembelian, dan pemanfaatan produk (Schiffman \& Kanuk, 2007)
Kelengkapan informasi (X2.3)

Kelengkapan fitur (X2.4)

Media komunikasi yang efektif (X2.5)

Konten instagram memotivasi (Y1)

Konten mempengaruhi pemilihan destinasi (Y2)

Konten mempengaruhi rencana aktivitas (Y3)

Kesediaan wisatawan membagikan konten (Y4)
Skala Likert Skala Likert Skala Likert Skala Likert Skala Likert Skala Likert Skala Likert

Sumber: Cowden (2014); Dennis (2014); Schiffman \& Kanuk (2007)

\section{Hasil Penelitian}

Dari Data responden dikumpulkan menggunakan lima karakteristik, yakni jenis kelamin, umur, status perkawinan, Pendidikan, dan pekerjaan. Data responden disajikan pada Tabel 3.

Tabel 3. Karakteristik Responden

\begin{tabular}{llllllll}
\hline No & Responden & F & $\mathbf{\%}$ & No & Responden & F & $\mathbf{\%}$ \\
\hline 1 & Jenis Kelamin & & & 4 & Pendidikan & & \\
& Pria & 91 & $45,5 \%$ & & SMP & 1 & $5 \%$ \\
& Wanita & 109 & $54,4 \%$ & & SLTA & 20 & $10 \%$ \\
2 & Umur & & & & Diploma & 50 & $25 \%$ \\
& $<$ 20 Tahun & - & - & & Sarjana & 40 & $20 \%$ \\
& 21-30 Tahun & 49 & $24,5 \%$ & & Pascasarjana & 89 & $44,5 \%$ \\
& 31-40 Tahun & 49 & $24,5 \%$ & 5 & Pekerjaan & & \\
& 41-50 Tahun & 40 & $20 \%$ & & ASN & 23 & $11,5 \%$ \\
& > 50 Tahun & 62 & $31 \%$ & & Peg.Swasta & 51 & $25,5 \%$ \\
3 & Perkawinan & & & & Wiraswasta & 17 & $8,5 \%$ \\
& Menikah & 124 & $62 \%$ & & Pelajar & 50 & $25 \%$ \\
& Tidak & 76 & $38 \%$ & & Lain-lain & 59 & $29,5 \%$ \\
& Menikah & & & & & & \\
\hline
\end{tabular}

Sumber: Hasil Penelitian (2021)

Penelitian menggunakan tiga variabel, yang terdiri dari dua variabel $\mathrm{X}$ dan satu variabel $\mathrm{Y}$. Variabel $\mathrm{X}$ meliputi kemampuan wisatawan mengakses instagram dan persepsi responden terhadap kualitas Instagram, sedangkan variabel $\mathrm{Y}$, yakni minat kunjungan wisatawan. Data variabel penelitian menggunakan 3 variabel terdiri dari 17 pernyataan, seperti disajikan pada Tabel 4.

Tabel 4. Data Survei

\begin{tabular}{|c|c|c|c|c|c|c|c|c|c|c|}
\hline \multirow{2}{*}{$\begin{array}{l}\text { Var/ } \\
\text { Likert }\end{array}$} & \multicolumn{2}{|c|}{1} & \multicolumn{2}{|c|}{2} & \multicolumn{2}{|c|}{3} & \multicolumn{2}{|c|}{4} & \multicolumn{2}{|c|}{5} \\
\hline & $\mathbf{F}$ & $\%$ & $\mathbf{F}$ & $\%$ & $\mathbf{F}$ & $\%$ & $\mathbf{F}$ & $\%$ & $\mathbf{F}$ & $\%$ \\
\hline $\mathrm{X} 1.1$ & 1 & 0,5 & 2 & 1 & 13 & 6,5 & 55 & 27,5 & 129 & 64,5 \\
\hline $\mathrm{X} 1.2$ & - & - & 2 & 1 & 13 & 6,5 & 70 & 35 & 115 & 57,7 \\
\hline $\mathrm{X} 1.3$ & 1 & 0,5 & - & - & 19 & 9,5 & 69 & 34,5 & 111 & 55,5 \\
\hline $\mathrm{X} 1.4$ & 1 & 0,5 & 3 & 1,5 & 20 & 10 & 65 & 32,5 & 111 & 55,5 \\
\hline $\mathrm{X} 1.5$ & - & - & 2 & 1 & 11 & 5,5 & 71 & 35,5 & 116 & 58 \\
\hline X1.6 & - & - & 2 & 4 & 36 & 18 & 79 & 39,5 & 81 & 40,5 \\
\hline $\mathrm{X} 1.7$ & 1 & 0,5 & 4 & 2 & 29 & 14,5 & 87 & 43,5 & 79 & 39,5 \\
\hline $\mathrm{X} 1.8$ & 6 & 3 & 6 & 3 & 30 & 15 & 81 & 40,5 & 77 & 38,5 \\
\hline $\mathrm{X} 2.1$ & 2 & 10 & 1 & 0,5 & 30 & 15 & 80 & 40 & 87 & 43,5 \\
\hline $\mathrm{X} 2.2$ & 1 & 0,5 & 3 & 1,5 & 26 & 13 & 85 & 42,5 & 85 & 42,5 \\
\hline X2.3 & 1 & 0,5 & 2 & 1 & 22 & 11 & 89 & 44,5 & 86 & 43 \\
\hline X2.4 & 3 & 1,5 & 1 & 0,5 & 38 & 19 & 96 & 48 & 62 & 311 \\
\hline $\mathrm{X} 2.5$ & 1 & 0,5 & - & - & 32 & 16 & 92 & 46 & 75 & 37 \\
\hline Y1 & 1 & 0,5 & - & - & 25 & 12,5 & 84 & 42 & 90 & 45 \\
\hline Y2 & 1 & 0,5 & 1 & 0,5 & 23 & 11,5 & 76 & 38 & 99 & 49,5 \\
\hline Y3 & 1 & 0,5 & 1 & 0,5 & 26 & 13 & 84 & 42 & 88 & 44 \\
\hline Y4 & 2 & 1 & 3 & 1,5 & 37 & 18,5 & 88 & 44 & 70 & 35 \\
\hline
\end{tabular}

Sumber: Hasil Penelitian (2021) 
Hasil analisa data mencatat variabel $\mathrm{X} 1$ dan $\mathrm{X} 2$ berpengaruh positif signifikan terhadap variabel Y, baik secara parsial maupun simultan, seperti disajikan pada Tabel 5.

Tabel 5. Analisis Linear

\begin{tabular}{|c|c|c|c|c|}
\hline \multirow[t]{2}{*}{ Model } & \multicolumn{4}{|c|}{ Coefficients $^{\mathrm{a}}$} \\
\hline & B & SE & $t$ & Sig. \\
\hline 1 (Constant) & 1,694 & 1,093 & 1,551 & 0,123 \\
\hline $\mathrm{X} 1$ & 0,199 & 0,034 & 5,859 & 0,000 \\
\hline \multirow[t]{3}{*}{$\mathrm{X} 2$} & 0,400 & 0,044 & 9,068 & 0,000 \\
\hline & \multicolumn{4}{|c|}{ ANOVA $^{b}$} \\
\hline & SS & df & $\mathbf{F}$ & Sig. \\
\hline 1 Regression & 785,603 & 2 & 112,019 & $.000^{\mathrm{a}}$ \\
\hline \multirow[t]{3}{*}{ Residual } & 690,792 & 197 & & \\
\hline & \multicolumn{4}{|c|}{ Model Summary } \\
\hline & $\mathbf{R}$ & $\mathbf{R}^{2}$ & Adj. $\mathbf{R}^{2}$ & SEE \\
\hline 1 & $0,729^{\mathrm{a}}$ & 0,532 & 0,527 & 1,87258 \\
\hline
\end{tabular}

Dari data pada Tabel 4 dapat dirumuskan persamaan dan model regresi linear, seperti terlihat pada Gambar 2.

$$
\begin{aligned}
& Y=a+b_{1} X_{1}+b_{2} X_{2}+e \\
& Y=1,694+0,199 X_{1}+0,400 X_{2}+e
\end{aligned}
$$

Persamaan tersebut dapat dijabarkan, bahwa angka 1,694 merupakan nilai konstanta, sedangkan nilai yang melekat pada X1 dan X2, yakni 0,199 dan 0,400 merupakan besar pengaruh variabel Independent atau variabel bebas, yakni $\mathrm{X} 1$ maupun $\mathrm{X} 2$ terhadap variabel dependent atau variabel terikat, yakni Y. Sedangkan e atau error merupakan residual, yakni nilai kesalahan dalam memprediksi data sampel. Besar nilai e dapat dihitung dari nilai $\mathrm{R}$ square, dengan rumus $\sqrt{ } 1-0,532$, yakni 0,68 . Dari Tabel 4 tercatat bahwa nilai signifikan kemampuan wisatawan mengakses Instagram (X1) sebesar 0,000, < 0,05, maka H0 ditolak dan H1 diterima, yakni terdapat pengaruh positif signifikan variabel kemampuan mengakses Instagram dengan minat kunjungan wisata. Demikian juga dengan nilai signifikan kualitas Instagram juga sebesar $0,000<0,05$, maka $\mathrm{H} 0$ ditolak dan $\mathrm{H} 1$ diterima, berarti terdapat pengaruh positif signifikan variabel kualitas Instagram terhadap minat kunjungan wisata. Adapun dilihat dari nilai koefisien beta (B) tercatat nilai X2 > X1, berarti variabel kualitas Instagram mempunyai pengaruh yang lebih dominan terhadap minat kunjungan wisata yakni sebesar 40\%, dibandingkan dengan kemampuan wisatawan mengakses Instagram yakni sebesar 19,9\%.

Gambar 2. Model Regresi Linear

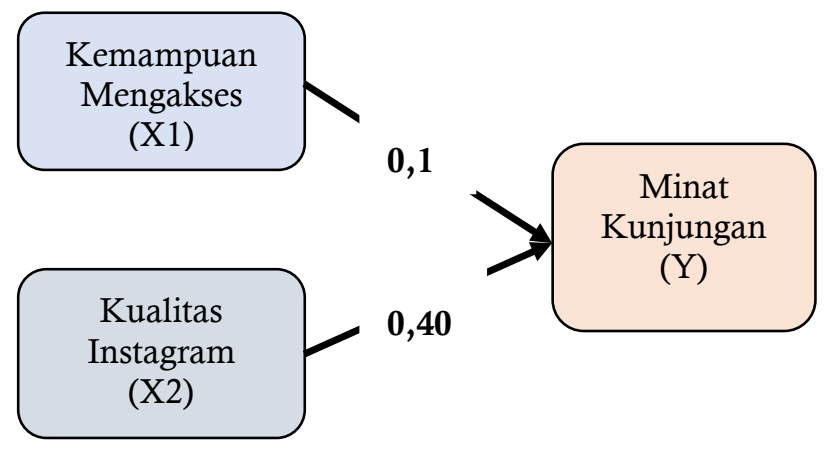

Sumber: Hasil Penelitian (2021)

Hasil uji linearitas menggunakan SPSS menunjukkan nilai-nilai sebaran data terletak di sekitar garis lurus, maka dapat disimpulkan normalitas data terpenuhi. Data yang dipakai dalam 
penelitian ini memenuhi persyaratan yang diperlukan oleh uji parametrik serta memiliki varians data yang homogen. Uji linearitas ini sangat diperlukan untuk mengetahui kualitas data yang digunakan. Dalam hal ini berdistribusi normal atau diambil dari populasi normal, seperti terlihat pada Gambar 3

Gambar 3. Normal P-Plot of Regression Standardized Residual Dependent Variable: Minat Kunjungan $(Y)$

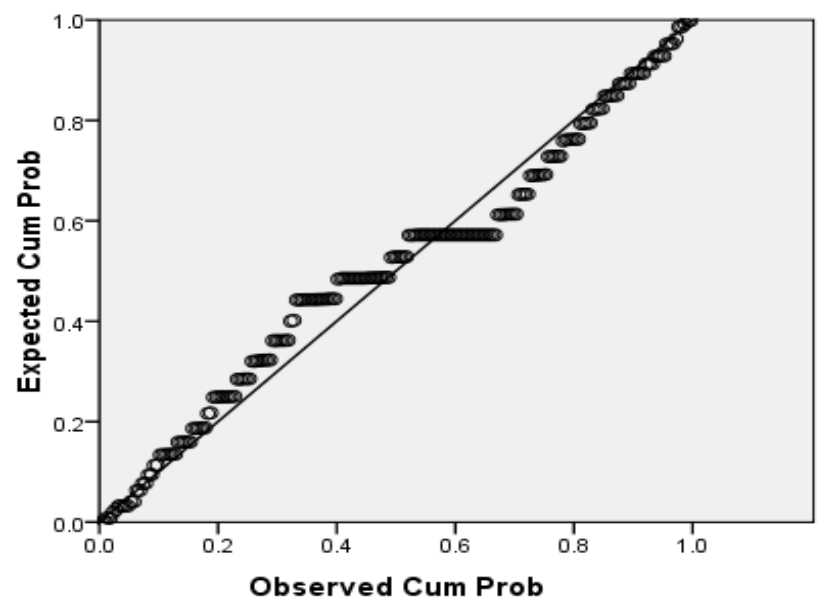

Sumber: Hasil Penelitian (2021

\section{Pembahasan}

Daerah Istimewa Yogyakarta (D.I.Y) terletak di bagian selatan Pulau jawa, berbatasan dengan Provinsi Jawa tengah dan Samudera Hindia. D.I.Y terbagi menjadi empat kabupaten dan satu kota, yakni Kabupaten Sleman, Kabupaten Bantul, Kabupaten Kulon Progo, Kabupaten Gunungkidul, dan Kota Yogyakarta. Daerah Istimewa Yogyakarta mempunyai luas 3.185,80 kilometer persegi atau 0,17 dari luas Indonesia. D.I.Y yang pernah menjadi Ibu kota negara menyimpan banyak sejarah yang menarik sebagai destinasi wisata.

D.I.Y merupakan destinasi wisata yang banyak diminati oleh wisatawan, karena potensi wisata yang sangat beragam, meliputi; wisata alam, pantai, budaya, sejarah, museum, minat khusus, buatan, dan desa/kampung wisata. Selain daya tarik wisata, D.I.Y juga menawarkan makanan khas yang sangat terkenal sampai mancanegara, diantaranya Gudeg dan Bakpia. Atraksi wisata dan kuliner yang ditawarkan menjadi lengkap dengan sikap keramah-tamahan penduduk lokal. Masyarakat D.I.Y terkenal dengan budaya yang ramah dan murah senyum, sehingga membuat nyaman dan betah setiap wisatawan yang berkunjung ke D.I.Y.

Potensi wisata yang dimiliki D.I.Y tidak kalah dengan destinasi di daerah lain, bahkan masih banyak potensi yang belum terekspos dan mampu menjadi magnet bagi wisatawan. Namun demikian, promosi dan pemasaran yang strategis harus diimplementasikan agar jumlah kunjungan wisatawan dapat terus ditingkatkan. Promosi dan pemasaran yang tidak tepat akan memberi peluang berkurangnya wisatawan yang berkunjung ke D.I.Y. Masa pandemi yang sudah berlangsung satu tahun lebih telah merubah pola perilaku wisatawan yang harus diikuti dengan perubahan strategi promosi dan pemasaran. Pemasaran secara online, menggunakan media sosial menjadi pilihan utama karena pembatasan mobilitas. Salah satu media sosial yang digunakan untuk promosi dan pemasaran destinasi wisata di D.I.Y, yakni Instagram. Pemilihan Instagram sebagai alat promosi dan pemasaran tentunya didasari beberapa petimbangan, yakni fitur yang dimiliki, trend pengguna yang terus meningkat, efisiensi, dan efektifitas (Bevins, 2014; Herman, 2014; Hird, 2013; Linaschke, 2011; Silva et al., 2013). Instagram merupakan aplikasi yang sangat fleksibel karena mampu terkoneksi dengan media sosial lain, seperti Facebook, 
sehingga memudahkan dalam melakukan posting ke beberapa media sosial secara langsung. Sistem promosi dan pemasaran seperti ini mampu menjangkau pasar yang besar dan skala luas.

Namun demikian, Instagram juga mempunyai beberapa kekurangan yang harus menjadi perhatian bagi pengelola untuk mempertahankan kinerja pemasaran. Penggunaan Instagram sebagai media promosi dan pemasaran belum mampu menjangkau semua pasar, karena terdapat wisatawan kurang memahami teknologi. Dalam hal ini, penggunaan Instagram berpotensi pada kehilangan pasar yang tidak mampu mengaksesnya, sehingga strategi promosi dan pemasaran menggunakan alternatif lain juga tetap dipertimbangkan. Semakin berkembangnya teknologi maka, semakin besar tingkat persaingan, tidak terkecuali persaingan pemasaran melalui Instagram juga semakin ketat. Kemudahan berkomunikasi pada Instagram menyulitkan pengelola untuk menyaring informasi yang masuk. Review atau ulasan buruk yang belum tentu sesuai dengan kenyataan tidak terhindarkan, hal ini tentunya sangat berpengaruh terhadap reputasi sebuah destinasi wisata.

Penelitian ini bertujuan untuk mengulas sejauhmana efektifitas Instagram sebagai alat promosi dan pemasaran destinasi wisata di D.I.Y dalam meningkatkan minat kunjungan wisatawan. Dinas Parawisata D.I.Y mempunyai Instagram dengan akun visitingjogja.com, yang mempunyai pengikut terbanyak dibandingkan media sosial lain, yakni YouTube, facebook, dan Twitter. Jumlah follower atau Facebook sebanyak 3.866 orang, sedangkan YouTube hanya sebanyak 80 subcriber. Pengikut Instagram Dinas Pariwisata D.I.Y paling besar yakni 11,9 ribu, seperti terlihat pada Gambar 4.

Gambar 4. Instagram Dinas Pariwisata D.I.Y

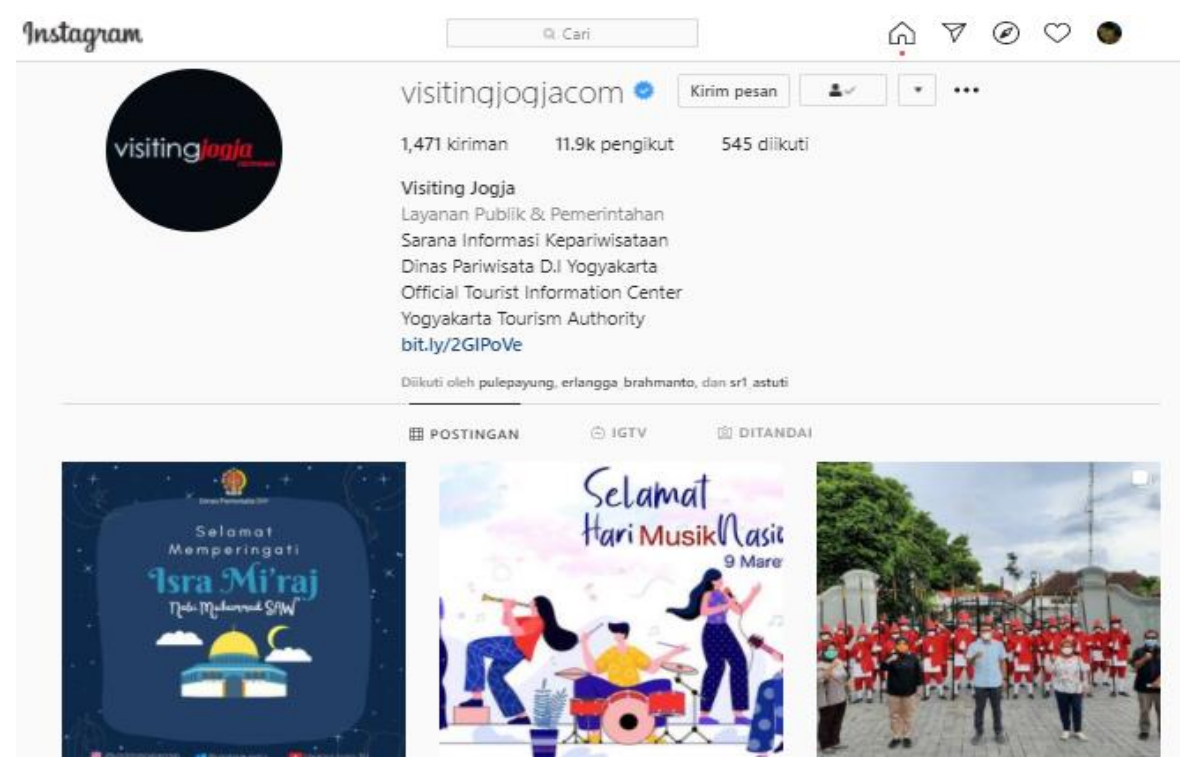

Sumber: Dinas Pariwisata D.I.Y (2021)

Konten Instagram Dinas Pariwisata D.I.Y relative sangat menarik dengan informasi yang up to date Hal ini tentunya menjadi daya tarik utama bagi wisatawan untuk selalu mengakses Instagram guna mendapatkan informasi berbagai atraksi wisata yang digelar di D.I.Y. Konten yang disajikan di Instagram D.I.Y, meliputi berbagai atraksi wisata yang menjadi daya tarik wisata, diantaranya budaya, kuliner, sejarah, alam, maupun wisata buatan. Selain itu, Instagram juga menyajikan berbagai event yang diselenggarakan di D.I.Y, sehingga wisatawan bisa mengatur agenda perjalanan wisata sesuai dengan atraksi wisata atau event yang diinginkan.

Dari hasil survei terhadap 200 responden tercatat pengunjung pria dan wanita cukup merata, yakni 54\% wanita dan 45\% Pria, dengan status menikah mendominasi yakni $62 \%$. Dari aspek umur, tercatat mayoritas berumur 50 tahun keatas yakni $31 \%$ sedangkan pada range usia $21 \mathrm{s.d}$ 50 tahun relatif merata, yakni rata-rata $24 \%$. Pendidikan responden didominasi pascasarjana, 
yakni 44,5\%. Adapun pekerjaan responden merata sebagai pegawai swasta, pelajar, dan lain-lain, masing-masing 50\%, sedangkan sebagai ASN dan wiraswasta relatif sedikit yakni kurang dari $12 \%$, seperti disajikan pada Tabel 3 .

Hasil analisa data pada Tabel 5 menunjukkan bahwa variabel kemudahan mengakses media sosial dan kualitas Instagram berpengaruh positif signifikan terhadap variabel minat kunjungan, baik secara parsial maupun simultan. Pengaruh secara parsial, terlihat dari nilai signifikansi lebih besar dari 0,05 dan nilai thitung lebih besar dari t tabel yakni 2,345, sedangkan secara simultan terlihat dari nilai f hitung sebesar 112,019 lebih besar dari f tabel sebesar 3,04. Nilai t tabel diambil dari Tabel T, dengan ketentuan jumlah responden (n) sebesar 200, jumlah variabel (k) sebanyak 3, dan nilai signifikansi 5\%. Demikian juga nilai $\mathrm{f}$ tabel diambil dari Tabel $\mathrm{F}$ dengan ketentuan sama dengan $\mathrm{t}$ tabel.

Nilai konstanta sebesar 1,694 menunjukkan pengaruh positif kemampuan wisatawan mengakses dan kualitas Instagram terhadap minat kunjungan. Kenaikan satu satuan pada nilai kemampuan mengakses akan menaikkan nilai variabel minat kunjungan sebesar 0,199 satuan atau $19,9 \%$, sedangkan kenaikan satu satuan pada kualitas Instagram akan menaikkan nilai minat kunjungan sebesar 0,400 satuan atau $40 \%$. Kualitas Instagram mempunyai pengaruh yang dominan terhadap minat kunjungan wisata yakni sebesar $40 \%$, sedangkan kemampuan mengakses berpengaruh sebesar 19,9\%. Besar kontribusi variabel kemampuan mengakses dan kualitas Instagram terhadap minat kunjungan sebesar 0,532 atau 53,2\%. Hal ini menunjukkan bahwa sebesar $53,2 \%$ variasi variabel minat kunjungan dapat dijelaskan oleh variabel kemampuan mengakses dan kualitas Instagram sebesar 53,2\%, sedangkan sisanya sebesar 46,8\% dipengaruhi oleh variabel lain yang tidak dilibatkan dalam penelitian ini.

Kualitas Instagram dinilai dari tampilan yang menarik, informasi yang up to date, kelengkapan informasi, kelengkapan fitur, dan media komunikasi yang efektif (Madahi \& Sukati, 2012). Kelima variabel tersebut mempunyai pengaruh yang dominan terhadap minat wisatawan berkunjung berkunjung ke D.I.Y. Konten yang menarik, lengkap, dan up to date pada Instagram visitingjogja.com mempengaruhi wisatawan untuk berkunjung di D.I.Y. Selain itu, Instagram menjadi sarana komunikasi antara wisatawan dengan pengelola, maupun antara wisatawan, sehingga menjadi preferensi yang kuat untuk berkunjung (Trihayuningtyas et al., 2019). Komunikasi melalui Instagram terbangun dari proses review atau ulasan terhadap sebuah destinasi atau atraksi wisata. Video atau foto dan review yang diposting pada Instagram merupakan salah satu bentuk berbagi pengalaman, sehingga dianggap sebagai referensi yang kuat bagi wisatawan yang akan berkunjung. Dalam hal ini ulasan atau review positif terhadap wisata di D.I.Y mampu meningkatkan kunjungan wisatawan, namun sebaliknya ulasan atau review negatif berdampak pada menurun atau hilangnya minat kunjungan. Efektifitas komunikasi melalui Instagram dapat ditingkatkan melalui pengoptimalan pemanfaatan fitur dan penggunaan public figure sebagai pembawa pesan bagi wisatawan(Kusuma \& Sugandi, 2019). Public figure mampu menjadi influencer bagi wisatawan yang ingin berkunjung ke destinasi wisata.

Kualitas Instagram sebagai variabel yang berpengaruh dominan terhadap minat kunjungan sangat ditentukan oleh konten yang disajikan. Dalam mendesain konten perlu memperhatikan beberapa hal, yakni kualitas gambar, durasi waktu, dan narasi yang disajikan. Kualitas gambar yang bagus pada video maupun foto yang ditampilkan pada Instagram mempengaruhi minat pengguna untuk menyimak dengan seksama. Durasi waktu penayangan video harus diperhatikan dan disesuaikan dengan waktu ideal seseorang menonton video. Video yang ditayangkan terlalu lama hanya akan menimbulkan kebosanan dan tidak ditonton sampai tuntas, sehingga informasi atau pesan yang disampaikan pada bagian akhir tidak akan tersampaikan. Rata-rata waktu ideal yang digunakan untuk menonton tayangan video, yakni dua menit. Dalam hal ini desain video yang singkat, padat, dan interaktif sangat diperlukan untuk mempertahankan jumlah viewer. Video pendek dapat didesain tanpa menghilangkan informasi atau bagian penting dari video tersebut. Penayangan video pada Instagram dapat menggunakan fitur Intagram TV (IGTV). Fitur 
ini memungkinkan untuk menggugah video berisi review destinasi wisata, produk kuliner, eventevent yang digelar di D.I.Y, dan lain sebagianya. Review yang disampaikan oleh tokoh atau public figure akan lebih kuat dalam mempersuasi wisatawan, karena mereka merupakan role model yang mampu menciptakan trend-trend untuk ditiru masyarakat luas. Selain kualitas gambar dan durasi, narasi atau cerita yang dikemas dalam sebuah video dan foto menjadi informasi, sekaligus referensi kuat bagi wisatawan. Narasi yang tajam, fokus, dan spesifik mampu membentuk opini dan mempengaruhi untuk wisatawan untuk berkunjung ke sebuah destinasi wisata.

Variabel kemudahan akses, yang terdiri dari aspek perangkat, kuota, kemampuan mengakses, tempat dan waktu mengakses, dan ketersediaan waktu yang cukup tidak berpengaruh secara dominan terhadap minat kunjungan wisatawan. Hal ini sesuai dengan kondisi saat ini, dimana pemerintah memfasilitasi kemudahan akses diantaranya melalui penyediaan fasilitas umum dan wifi gratis. Fasilitas umum yang disediakan pemerintah tentunya memberi kemudahan dalam mengakses media sosial, sehingga keterbatasan perangkat dan paket data tidak menghalangi wisatawan untuk mengakses Instagram. Kelengkapan fasilitas wisata menjadi keharusan dalam mewujudkan pengalaman wisata yang berkualitas. Ketersediaan wifi pada berbagai area tidak hanya memberi keuntungan bagi wisatawan, namun juga bagi pengelola destinasi wisata. Wifi tidak hanya mempermudah wisatawan dalam mengakses informasi, namun juga digunakan untuk berbagi informasi dengan cara mengupload foto dan video melalui media sosial, salah satunya Instagram. Wisatawan selalu ingin membagikan foto dan video secara realtime sebagai bentuk eksistensi diri. Foto dan video yang dibagikan wisatawan secara tidak langsung membantu proses promosi dan pemasaran sebuah destinasi wisata.

Penguatan promosi dan pemasaran melalui platform Instagram menjadi sangat strategis dilakukan pada masa pandemi Covid-19, dimana mobilitas wisatawan sangat terbatas. Pengelola destinasi wisata dapat memaksimalkan pemanfaatan Instagram untuk menawarkan produk wisata dengan menjangkau pasar yang luas dalam waktu yang relative singkat. Instagram merupakan salah satu media sosial yang banyak diminati, terutama dimasa pandemi covid saat ini. Melalui Instagram wisatawan dapat melihat kualitas destinasi dari berbagai review yang dibagikan oleh wisatawan. Dalam hal ini, kualitas konten yang selalu up to date dari pengelola sangat penting dalam mempengaruhi keputusan wisatawan untuk mengunjungi sebuah destinasi wisata.

\section{Kesimpulan}

Dinas pariwisata D.I.Y menggunakan Instagram sebagai media promosi dan pemasaran yang paling efektif dan efisien dibandingkan media sosial lain. Pemanfaatan Instagram dengan mempertimbangkan kelengkapan fitur yang dimiliki, serta fasilitas komunikasi yang efektif antara wisatawan dengan pengelola dan antara wisatawan sendiri. Instagram terbukti mampu menjangkau pasar yang cukup besar dan luas, terlihat dari jumlah follower yang jauh lebih banyak dibanding media lainnya. Kualitas Instagram mempunyai pengaruh yang dominan terhadap minat kunjungan dibandingkan kemampuan wisatawan dalam mengakses Instagram. Kualitas Instagram memberi pengaruh kuat dalam membentuk opini seorang wisatawan untuk berkunjung ke destinasi wisata. Adapun kemampuan wisatawan yang diantaranya meliputi ketersediaan perangkat dan kuota tidak dominan, karena Dinas pariwisata D.I.Y telah menyediakan fasilitas public yang mendukung aksesibilitas media sosial, salah satunya wifi gratis pada berbagai area.

\section{Konflik Kepentingan}

Penulis menyatakan tidak ada konflik kepentingan dalam penulisan artikel ini. 


\section{Daftar Pustaka}

Atiko, G., Hasanah Sudrajat, R., \& Nasionalita, K. (2016). Analisis Strategi Promosi Pariwisata Melalui Media Sosial Oleh Kementrian Pariwisata RI (studi deskriptif pada akun Instagram

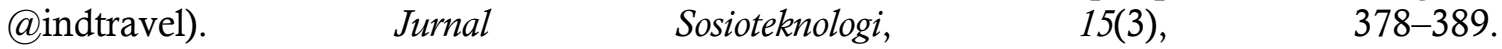
https://doi.org/10.5614/sostek.2016.15.3.6

Baker, A. M., \& Donthu, N. (2015). (C) 2015, American Marketing Association. 404-413.

Bergström, T., \& Bäckman, L. (2013). Marketing and PR in Social Media : How the utilization of Instagram builds and maintains customer relationships. Media and Communication, 56.

Bevins, C. (2014). Get Schooled: A Visual Social Semiotic Analysis of Target's Branding using Instagram. Zhurnal Eksperimental'noi i Teoreticheskoi Fiziki, 1-133.

Carah, N., \& Shaul, M. (2016). Brands and Instagram: Point, tap, swipe, glance. Mobile Media and Communication, 4(1), 69-84. https://doi.org/10.1177/2050157915598180

Cowden, A. . (2014). Effect of Social Media Marketing on Traditional Marketing Campaigns in Young Icelandic Companies. Reykjavik.

Dennis, D. (2014). Successfully Social: A Non-Profit's Guide to Modern Social Media Marketing. Senior Honours Thesis, 1-32.

Deru, R. ., \& Cindy, J. (2017). Media Sosial Instagram Sebagai Sarana Promosi Untuk Meningkatkan Minat Beli Konsumen. Jurnal Bisnis Terapan, 1(01), 25-32. https://doi.org/10.24123/jbt.v1i01.296

Dewing, M. (2017). Social media: An Introduction. Parliamentary Information and Research Service, Social Affairs Division. Canada: Library of Parliament.

Djafarova, E., \& Rushworth, C. (2017). Exploring the credibility of online celebrities' Instagram profiles in influencing the purchase decisions of young female users. Computers in Human Behavior, 68, 1-7. https://doi.org/10.1016/j.chb.2016.11.009

Dobele, A., Lindgreen, A., Beverland, M., Vanhamme, J., \& van Wijk, R. (2007). Why pass on viral messages? Because they connect emotionally. Business Horizons, 50(4), 291-304. https://doi.org/10.1016/j.bushor.2007.01.004

Doh, S. J., \& Hwang, J. S. (2009). How consumers evaluate eWOM (electronic word-of-mouth) messages. Cyberpsychology and Behavior, 12(2), 193-197. https://doi.org/10.1089/cpb.2008.0109

Ellya. (2015). Promosi Wisata Lebih Cepat Lewat Sosmed dan Media Sosial.

Goyette, I., Ricard, L., \& Bergeron, J. (2010). e-WOM Scale : Word-of-Mouth Measurement Scale for e-Services Context *. 23, 5-23.

Herman, J. (2014). How to use Instagram to improve your marketing.

Hird, C. (2013). Social media marketing: A best practices analysis of selected destination magazines.

Hudson, S., \& Hudson, D. (2006). Branded Entertainment: A New Advertising Technique or Product Placement in Disguise? Journal of Marketing Management, 22(5-6), 489-504. https://doi.org/10.1362/026725706777978703

Jadhav, N.P, Kamble, R, S., \& Patil, M. . (n.d.). Social Media Marketing: The Next Generation of Business Trends. IOSR Journal of Computer Engineering (IOSR-JCE), 45-49.

Jalilvand, M. R., \& Samiei, N. (2012). The effect of electronic word of mouth on brand image and purchase intention: An empirical study in the automobile industry in Iran. Marketing Intelligence and Planning, 30(4), 460-476. https://doi.org/10.1108/02634501211231946

Kim, A. J., \& Ko, E. (2012). Do social media marketing activities enhance customer equity? An empirical study of luxury fashion brand. Journal of Business Research, 65(10), 1480-1486. https://doi.org/10.1016/j.jbusres.2011.10.014

Knibbs, K. (2013). Want to make money? Study says Instagram beats Twitter, Facebook in brand engagement.

Kurniawati, W. D. N. (2017). Pemanfaatan Instagram Oleh Komunitas Wisata Grobogan Dalam Mempromosikan Potensi Pariwisata Daerah. Komuniti: Jurnal Komunikasi Dan Teknologi Informasi, 8(5), 127. https://doi.org/10.23917/komuniti.v8i5.2943

Kusuma, D. F., \& Sugandi, M. S. (2019). Strategi Pemanfaatan Instagram Sebagai Media Komunikasi Pemasaran Digital Yang Dilakukan Oleh Dino Donuts. Jurnal Manajemen Komunikasi, 3(1), 18. https://doi.org/10.24198/jmk.v3i1.12963 
Kwek, C. L., Tan, H. P., \& Lau, T. C. (2010). Investigating the shopping orientations on online purchase intention in the e-commerce environment: A Malaysian study. Journal of Internet Banking and Commerce, 15(2), 1-22.

Lin, T. M. ., Lu, K., \& Wu, J. (2012). The effects of visual information in eWOM communication. Journal of Research in Interactive Marketing, 6(1), 7-26. https://doi.org/10.1108/17505931211241341

Linaschke, J. (2011). Getting the most from Instagram. Berkeley: Peachpit Press.

Madahi, A., \& Sukati, I. (2012). The Effect of External Factors on Purchase Intention amongst Young Generation in Malaysia. International Business Research, 5(8). https://doi.org/10.5539/ibr.v5n8p153

Maravic, A. (2013). Through the photo-chromic lens of the beholder: The development of the simple holiday photography to a marketing product. Modul Vienna.

Martin, K., \& Todorov, I. (2010). How Will Digital Platforms be Harnessed in 2010, and How Will They Change the Way People Interact with Brands? Journal of Interactive Advertising, 10(2), 61-66. https://doi.org/10.1080/15252019.2010.10722170

Nasrullah, R. (2015). Media Sosial: Prosedur, Tren, dan Etika. Bandung: Simbiosa Rekatama Media.

Neti, S. (2011). Social media and its role in marketing. International Journal of Enterprise Computing and Business Systems, 1(2), 1-14.

Rezvani, S., Dehkordi, G. J., Rahman, M. S., Fouladivanda, F., Habibi, M., \& Eghtebasi, S. (2012). A conceptual study on the country of origin effect on consumer purchase intention. Asian Social Science, 8(12), 205-215. https://doi.org/10.5539/ass.v8n12p205

Rochman, A., \& Iskandar, P. (2015). Users' Engagement Toward the Brand Accounts in Instagram Based on the Aisas Model. Journal of Business and Management, 4(8), 890-900.

Saravanakumar, M; Lakshmi, T. . (2012). Social media marketing. Life Science Journal, 9(4).

Schiffman, L. ., \& Kanuk, L. L. (2007). Consumer Behavior, ninth ed. New Jersey: Prentice-Hall Inc.

Setiawan, E. B. (2017). Quality and Purchase Intention Percieved Towards low Cost EnergySaving Cars. Jurnal Manajemen Transportasi Dan Logistik, 2(1), 107. https://doi.org/10.25292/j.mtl.v2i1.135

Shih, T.-Y. (2010). Comparative Analysis of Marketing Strategies for Manufacturers' and Retailers' Brands. International Journal of Electronic Business Management, 8(1), 56-67.

Silva, T. H., Melo, P. O. S. V. De, Almeida, J. M., Salles, J., \& Loureiro, A. A. F. (2013). A picture of instagram is worth more than a thousand words: Workload characterization and application. Proceedings - IEEE International Conference on Distributed Computing in Sensor Systems, DCoSS 2013, (i), 123-132. https://doi.org/10.1109/DCOSS.2013.59

Sugiyono. (2011). Metode Penelitian Kuantitatif Kualitatif dan R\&D. Bandung: Bandung: Alfabeta.

Teng, L., Laroche, M., \& Zhu, H. (2007). The effects of multiple-ads and multiple-brands on consumer attitude and purchase behavior. Journal of Consumer Marketing, 24(1), 27-35. https://doi.org/10.1108/07363760710720966

Trihayuningtyas, E., Wulandari, W., Adriani, Y., \& Sarasvati, S. (2019). Media Sosial Sebagai Sarana Informasi Dan Promosi Pariwisata Bagi Generasi Z Di Kabupaten Garut. Tourism Scientific Journal, 4(1), 1. https://doi.org/10.32659/tsj.v4i1.46

Uzunian, S. (2013). Factors affecting "Internet marketing" campaigns with reference to viral and permission marketing. The IUP Journal of Management Research, 9(1), 26-37.

Weber, L. (2007). Marketing to the Social Web: How Digital Customer Communities Build Your Bussiness. New Jersey: Wiley. 